\title{
Pengaruh Good Corporate Governance, Leverage dan Pertumbuhan Total Asset terhadap Nilai Perusahaan
}

\author{
Riyanto Setiawan Suharsono \\ Sekolah Tinggi Ilmu Ekonomi Kertanegara Malang \\ riyanto_setiawan@stiekma.ac.id
}

\begin{abstract}
Abstrak : Penelitian ini bertujuan untuk mengetahui pengaruh mekanisme Good Corporate Governance yaitu Kepemilikan Manajerial, Kepemilikan Institusional, Proporsi Dewan Komisaris Independen, Komite Audit serta Leverage dan Pertumbuhan Total Asset terhadap Nilai Perusahaan pada perusahaan manufaktur yang listing di Bursa Efek Indonesia (BEI). Nilai Perusahaan ditunjukkan oleh harga saham perusahaan. Metode pengambilan sampel yang digunakan adalah metode purposive sampling dengan dasar pemilihan sampel adalah perusahaan yang menerapkan prinsip-prinsip Good Corporate Governance selama periode observasi yaitu dalam tahun 2013- 2016. Berdasarkan kategori yang ditentukan, sampel yang digunakan selama kurun waktu 4 tahun adalah 96 perusahaan yang memenuhi kriteria. Dari hasil pengujian menunjukkan bahwa mekanisme Good Corporate Governance yaitu kepemilikan manajerial, kepemilikan institusional, komite audit dan leverage berpengaruh terhadap nilai perusahaan sedangkan proporsi dewan komisaris independen dan pertumbuhan total asset tidak berpengaruh secara parsial terhadap nilai perusahaan..
\end{abstract}

Kata Kunci : Good Corporate Governance, total asset, leverage, nilai perusahaan

\section{Pendahuluan}

Mekanisme Good Corporate Governance (GCG) mempunyai peran di suatu perusahaan untuk mendapatkan lapran keuangan yang berkualitas yang memiliki informasi laba. Tata kelola perusahaan diwujudkan dalam Good Corporate Governance (GCG) yang menjelaskan hubungan antara berbagai pihak dalam perusahaan yang menentukan bagaimana arah dan kinerja perusahaan (Monks \& Minow, 2001). Peran Good Corporate Goverance berfungsi menjadi penghubung dalam menciptakan iklim persaingan usaha yang sehat ini sehingga tercipta efektifitas penerapan prinsip-prinsip pengelolaan perusahaan yang baik didalam sebuah perusahaan (Kusadrianto,2007). Selain itu, Good Corporate Governance mempunyai peran lain dalam menciptakan kepercayaan inverstor terhadap perusahaan (Emirzon, 2007). Perusahaan mempunyai komitmen dan konsistensi menjalankan prinsip Good Corporate Governance dalam aktivitas perusahaannya dengan sendirinya menumbuhkan kepercayaan investor. Salah satu contoh adanya krisis yang melanda negara-negara Asia termasuk Indonesia di tahun 1997, disebabkan karena buruknya pengelolaan perusahaan yang dilakukan tanpa memperhatikan prinsip-prinsip Corporate Governance. Upaya pengembangan Good Corporate Governance ditujukan untuk mendorong optimalisasi alokasi atau penggunaan sumber daya perusahaaan agar pertumbuhan dan kesejahteraan pemilik perusahaan terjaga.

Nilai perusahaan dapat mencerminkan nilai asset yang dimiliki perusahaan seperti suratsurat berharga. Saham merupakan salah satu surat berharga yang dikeluarkan perusahaan, 
tinggi rendahnya harga saham banyak dipengaruhi oleh kondisi perusahaan. Pada umumnya, faktor keuangan merupakan kunci utama yang akan mempengaruhi nilai perusahaan. Faktor keuangan yang mempengaruhi nilai perusahaan yang dominan yaitu total asset. Semakin besar asset maka semakin banyak modal yang ditanam. (Murni dan Andriana, 2007). Gambaran mengenai struktur modal yang dimiliki perusahaan dapat dilihat tingkat risiko tidak tertagihnya suatu hutang/leverage. Leverage yang terlalu tinggi juga akan memberikan dampak negatip terhadap investor yang akan menanamkan modalnya, hal ini dikarenakan leverage yang terlalu tinggi akan menimbulkan risiko yang tinggi pula terhadap pengembalian atas investasi yang mereka tanamkan karena hutang akan menciptakan beban tetap berupa bunga yang harus dibayarkan oleh perusahaan.

Peranan Good Corporate Governance dalam kepemilikan manajerial di perusahaan manufaktur dapat dilihat dengan adanya kewenangan direksi dalam penentuan arah kebijakan dari suatu perusahaan. Direksi tidak boleh memiliki conflict of interest dalam memutuskan sesuatu serta mengambil kebijakan untuk kepentingan perusahaan. Peranan Good Corporate Governance dalam kepemilikan institusional dapat dilihat di perusahaan manufaktur dari kendali perusahaan oleh pemegang saham mayoritas yang dapat menentukan arah dan sasaran dari korporasi. Perusahaan dengan kepemilikan institusional yang besar (lebih dari 5\%) mengindikasikan kemampuannya untuk memonitor manajemen. Peranan Good Corporate Governance dalam proporasi dewan komisaris di perusahaan manufaktur adalah adanya dewan komisaris yang bertugas melakukan pengawasan secara umum dan/atau khusus sesuai dengan anggaran dasar serta memberi nasihat kepada Direksi, dan sesuai dengan Pedoman Umum good corporate governance (GCG) Indonesia, dewan komisaris ini merupakan faktor sentral dalam GCG karena mempunyai tugas untuk memastikan bahwa perusahaan melaksanakan GCG, yaitu secara legal bertanggung jawab untuk menetapkan sasaran korporat, mengembangkan kebijakan yang luas, dan menilai kinerja manajemen untuk meyakinkan bahwa perusahaan dijalankan secara baik. Peranan Good Corporate Governance dalam komite audit dapat dilihat di perusahaan manfaktur dengan adanya auditor internal yang bertugas melakukan sistem pengawasan internal perusahaan untuk memonitor kinerja manajemen.

\section{A. Tujuan Good Corporate Governance}

pada intinya adalah menciptakan nilai tambah bagi semua pihak yang berkepentingan (Arifin, 2005). Pihak-pihak tersebut adalah pihak internal yang meliputi dewan komisaris, direksi, karyawan, dan pihak eksternal yang meliputi investor, kreditur, pemerintah, masyarakat, dan pihak-pihak lain yang berkepentingan (stakeholders). ada hubungan yang signifikan antara struktur dan mekanisme good corporate governance dan kinerja keuangan perusahaan atau nilai perusahaan (Black et. al, 2002). Menurut Downes dan Goodman (1999) yang disebutkan Murwaningsari (2009), kepemilikan manajerial adalah para pemegang saham yang juga berarti dalam hal ini pemilik dalam perusahaan dari pihak manajemen yang secara aktif ikut dalam pengambilan keputusan pada suatu perusahaan yang bersangkutan. Perspektif teori keagenan merupakan dasar yang digunakan untuk memahami Good Corporate Governance. Hubungan keagenan adalah kontrak antara pemilik perusahaan (principal) dan management (agent) (Gusnadi, 2008). Menurut teori agensi, agent harus bertindak secara rasional untuk kepentingan prinsipalnya. Agen harus menggunakan keahlian, kebijaksanaaan, itikad baik dan tingkah laku yang wajar dan adil dalam memimpin perseroan (Surya, 2008). Namun dalam praktiknya timbul masalah (agency problem), karena ada kesenjangan kepentingan antara para pemegang saham sebagai para pemilik perusahaan dengan pihak pengurus atau manajemen sebagai agen. Pemilik memiliki 
kepentingan agar dana yang telah diinvestasikannya memberikan pendapatan yang maksimal, sedangkan pihak manajemen memiliki kepentingan terhadap perolehan insentif atas pengelolaan dana pemilik perusahaan. Konflik kepentingan ini akan menimbulkan biaya (cost) yang biasa disebut agency cost (Surya, 2008).

Menurut teori Managerial Firm (Williamson, 1964) seperti dikutip Gorris dan Fumas (1996), secara umum tipe kepemilikan dan kontrol suatu perusahaan suatu perusahaan dibagi menjadi dua yaitu 1). perusahaan dimiliki dan dikontrol dengan pemegang saham dan 2)perusahaan dimiliki dan dikontrol oleh manajemen. Teori Keagenan (Agency Theory) menurut Jensen dan Meckling (1976) mengasumsikan bahwa manajer akan bertindak secara oportunistik dengan mengambil keuntungan pribadi sebelum memenuhi kepentingan pemegang saham. Jensen dan Meckling (1976) mengungkapkan bahwa struktur kepemilikan ekuitas berpengaruh penting terhadap insentif manajerial dan nilai perusahaan. Mereka berargumen bahwa kepemilikan saham manajerial dapat mengurangi insentif manajer untuk mengkonsumsi kemewahan, menyedot kekayaan pemegang saham, atau terlibat dalam perilaku yang tidak memaksimumkan nilai lainnya. Dengan peningkatan kepemilikan manajerial yang lebih baik dapat menyelaraskan kepentingan manajer dan pemegang saham, sehingga dapat meningkatkan nilai perusahaan. Hal ini berarti, Kepemilikan manajerial berpengaruh pada nilai perusahaan (Murlela dan Islahuddin, 2008). Berdasarkan penelitian tersebut, maka hipotesis yang akan diuji: $\mathrm{H} 1=$ Good Corporate Governance melalui Kepemilikan manajerial berpengaruh positip terhadap nilai perusahaan.

Menurut Teori Keagenan (Agency Theory) oleh Jensen dan Meckling (1976) yang menyatakan bahwa perubahan struktur kepemilikan perusahaan dapat meningkatkan nilai perusahaan, hal ini dapat terjadi melalui leverage buy out (LBO) dimana terjadi perubahan struktur kepemilikan institusional melalui pembelian hutang perusahaan. Perubahan struktur kepemilikan institusional dapat juga terjadi melalui penawaran saham perdana ke publik. Stuktur kepemilikan institusional dalam proporsi yang besar akhirnya mempengaruhi nilai perusahaan. Nilai perusahaan dapat meningkat jika lembaga institusi mampu menjadi alat pemonitoran yang efektif. Hasil penelitian Bjuggren et al (2007) menemukan bahwa kepemilikan institusional berpengaruh terhadap nilai perusahaan. Berdasarkan penelitian tersebut, maka hipotesis yang akan diuji : $\mathrm{H} 2=$ Good Corporate Governance melalui Kepemilikan insitusional berpengaruh positip terhadap nilai perusahaan

Menurut Teori Keagenan (Agency Theory) dalam Jensen dan Meckling (1976) diperlukan suatu konsep yang lebih jelas mengenai perlindungan terhadap para stakeholders, yang menyangkut masalah-masalah konflik kepentingan dan biaya-biaya agensi yang akan timbul, sehingga berkembanglah suatu konsep baru yang memperhatikan dan mengatur kepentingan-kepentingan para pihak yang terkait dengan kepemilikan yang diwakili oleh manajemen dan pengoperasional (stakeholders) suatu perusahaan yang diwakili oleh dewan komisaris. Dewan komisaris sebagai puncak dari sistem pengelolaan internal perusahaan memiliki peranan terhadap aktivitas perusahaan. Komisaris independen mempunyai akuntabilitas yang tinggi didalam melakukan pengawasan, semakin baik pengawasan sebuah perusahaan, semakin baik kualitas pengungkapan informasi yang disampaikan. Penelitian Rustiarini (2010) menunjukkan bahwa komisaris independen berpengaruh positip pada nilai perusahaan. Berdasarkan penelitian tersebut, maka hipotesis yang akan diuji : H3= Good Corporate Governance melalui Proporasi dewan komisaris independen berpengaruh positip terhadap nilai perusahaan. 
Teori Keagenan (Agency Theory) dalam Jensen dan Meckling (1976) untuk mengurangi konflik internal, menyarankan adanya sistem pengawasan internal yang berfungsi untuk mengamankan investasi dan asset perusahaan. Pengawasan internal tersebut adalah proses untuk menciptakan kepastian atas kebenaran laporan keuangan serta efektivitas dan efisiensi pengelolaan perusahaan. Pengawasan internal ini dilakukan oleh Komite audit yang bertanggung jawab untuk mengawasi laporan keuangan, mengawasi audit eksternal, dan mengamati sistem pengandalian internal dapat mengurangi sifat opportunistic masnajemen dengan cara mengawasi laporan keuangan dan melakukan pengawasan pada audit eksternal. Komite audit meningkatkan integritas dan kredibilitas pelaporan keuangan melalui : (1) pengawasan atas proses pelaporan termasuk sistem pengendalian internal dan penggunaan prinsip akuntansi berterima umum, dan (2) mengawasi proses audit secara keseluruhan. Hasilnya mengindikasikan bahwa adanya komite audit memiliki konsekuensi pada laporan keuangan yaitu : (1). Berkurangnya pengukuran akuntansi yang tidak tepat, (2) berkurangnya pengungkapan akuntansi yang tidak tepat dan (3) berkurangnya tindakan kecurangan manajemen dan tindakan illegal. Pengawasan internal yang baik oleh komite audit dapat meningkatkan nilai perusahaan. Berdasarkan penelitian tersebut, maka hipotesis yang akan diuji : H4= Good Corporate Governance melalui komite audit berpengaruh positip terhadap nilai perusahaan

Semakin besar total asset diharapkan semakin besar hasil operasional yang dihasilkan oleh perusahaan. Peningkatan total asset yang diikuti peningkatan hasil operasi akan semakin menambah kepercayaan pihak luar terhadap perusahaan. Dengan meningkatnya kepercayaan pihak luar (kreditor) terhadap perusahaan, maka proporsi hutang semakin lebih besar daripada modal sendiri. Hal ini didasarkan pada keyakinan kreditor atas dana yang ditanamkan kedalam perusahaan dijamin oleh besarnya total asset yang dimiliki perusahaan. Pertumbuhan Total Asset (asset growth) diduga berpengaruh terhadap nilai perusahaan. Berdasarkan penelitian tersebut, maka hipotesis yang akan diuji: H5= Pertumbuhan Total Asset berpengaruh positip terhadap nilai perusahaan. Tingkat pertumbuhan (growth) dalam penelitian ini menggunakan persentase perubahan pada total asset dari tahun (t-1) terhadap tahun sekarang (t), sebagai proxy. Persentase tingkat pertumbuhan ini juga digunakan sebagai proxy growth dalam penelitian yang dilakukan oleh Song (2005).

Novaes (2002) menyatakan bahwa peningkatan leverage bisa memberikan dua macam signal, yaitu berita baik (good news) sekaligus berita buruk (bad news). Peningkatan leverage menunjukkan berita baik jika peningkatan tersebut merefleksikan kemampuan managemen untuk meningkatkan nilai. Sebaliknya, hal tersebut menunjukkan berita buruk jika manager melakukan peningkatan leverage karena terpaksa dan bukan karena alasan efisiensi. maka hipotesis yang akan diuji: H6= Leverage berpengaruh positip terhadap nilai perusahaan.

\section{METODE}

Desain penelitian yang digunakan yaitu penelitian kausalitas yang bertujuan untuk menganalisis hubungan-hubungan antara satu variabel dengan variabel lainnya (Umar, 2008). Peneliti menganalisis komponen Good Corporate Governance (GCG) yang terdiri dari variabel Kepemilikan Manajerial, variabel Kepemilikan Institusional, variabel Proporasi Dewan Komisaris Independen, variabel Komite Audit, variabel leverage, dan variabel Pertumbuhan Total Asset terhadap harga saham, dimana komponen variabel Good Corporate Governance (GCG) dan Pertumbuhan Total Asset 
merupakan variabel yang mempengaruhi (variabel independen), sedangkan Nilai Perusahaan yang ditunjukkan dengan harga saham merupakan variabel yang dipengaruhi (variabel dependen).

Populasi dalam penelitian ini yaitu 151 perusahaan yaitu seluruh perusahaan manufaktur yang terdaftar di Bursa Efek Indonesia periode 2013-2016. Sampel yang digunakan dalam penelitian ini ditentukan dengan menggunakan tehnik purposive sampling sampel sebanyak 96 perusahaan dari periode tahun 2013-2016. Kriteria dalam pengambilan sampel yaitu :

1. Perusahaan manufaktur yang terdaftar di Bursa Efek Indonesia selama periode 2013-2016.

2. Perusahaan tersebut mempublikasikan laporan keuangan yang telah diaudit selama periode 2013-2016

3. Laporan keuangan dipublikasikan dalam mata uang rupiah

4. 4. Perusahaan tersebut memiliki sekurang-kurangnya tiga anggota komite audit (BAPEPAM Nomor 03 tahun 2002) dan (KEP-103/MBU/2002)

Sumber data dalam penelitian ini bersumber dari website Bursa Efek Indonesia, www.idx.co.id. Adapun data yang dibutuhkan dalam penelitian ini adalah :

1. Informasi mengenai total asset perusahaan periode 2013-2016

2. Informasi mengenai harga saham penutupan (closing price) perusahaan pada akhir tahun periode 2013-2016

Variable independen yang digunakan dalam penelitian ini adalah komponen variabel Good Corporate Governance (GCG) yang terdiri dari Kepemilikan Manajerial, Kepemilikan Institusional, Dewan Komisaris Independen, Komite Audit, serta variabel Leverage dan variabel Pertumbuhan Total Asset. Variabel dependen yang digunakan dalam penelitian ini adalah Nilai Perusahaan. Kepemilikan Manajerial adalah jumlah kepemilikan saham oleh pihak manajemen dari seluruh modal saham perusahaan yang dikelola (Gideon, 2005). Indikator yang digunakan untuk mengukur kepemilikan manajerial adalah :

$$
\text { Kepemilikan Manajerial }=\frac{\text { Saham yang dimiliki manajemen }}{\text { Total saham }} \times 100 \%
$$

Kepemilikan Institusional adalah persentase saham yang dimiliki oleh institusi / perusahaan (Beiner et al, 2003). Variabel ini diukur berdasarkan persentase jumlah saham yang dimiliki institusi dari seluruh modal saham yang beredar. Perhitungan dari kepemilikan institusional adalah :

$$
\text { Kepemilikan Institusional }=\frac{\text { Saham yang dimiliki institusional }}{\text { Total saham yang beredar }} \times 100 \%
$$

Proporasi dewan komisaris independen diukur berdasarkan persentase jumlah anggota dewan komisaris independen dari seluruh jumlah komisaris perusahaan (Sukamulja, 2004). Perhitungan dari proporsi dewan komisaris independen:

Proporasi dewan komisaris independen

$$
=\frac{\text { Jumlah komisaris independen } \times 100 \%}{\text { Jumlah seluruh komisaris }}
$$


Keberadaan komite audit diukur berdasarkan persentase jumlah komite audit yang berasal dari komisaris independen dari seluruh jumlah anggota komite audit (Girsang, 2010). Perhitungan dari komite audit adalah :

Komite Audit $=$ Jumlah anggota komite audit independen x 100\% Jumlah seluruh anggota

Tingkat pertumbuhan (growth) dalam penelitian ini menggunakan persentase penjualan pada total asset dari tahun ( $\mathrm{t}-1)$ terhadap tahun sekarang $(\mathrm{t})$ sebagai proxy. Persentase tingkat pertumbuhan ini juga digunakan sebagai proxy growth dalam penelitian yang dilakukan Song (2005).

Persentase perubahan dalam total asset $=\underline{\text { Total Aset }(\mathrm{t})-\text { Total Aset }(\mathrm{t}-1)}$ Total Asset (t-1)

Leverage dalam penelitian diukur dengan cara yaitu menghitung rasio utang dengan nilai buku ekuitas (Debt Equity Ratio/DER)

\section{Debt Equity Ratio / DER = Total Liabilities $\times 100 \%$}

Total Ekuitas

Pengukuran nilai perusahaan menggunakan Tobin's Q yang dikembangkan oleh White at al, 2002. Tobin's Q diukur dengan rumus:

$$
Q=\frac{(\mathrm{EMV}+\mathrm{D})}{(\mathrm{EBV}+\mathrm{D})}
$$

Keterangan:

Q

$=$ Nilai Perusahaan

EMV $\quad=$ Nilai Pasar ekuitas $(\mathrm{EMV}=$ closing price $\mathrm{X}$ jumlah saham yang beredar)

D $\quad=$ Nilai buku dari total hutang

EBV $\quad=$ Nilai buku dari total aktiva

Untuk menganalisis data, peneliti membuat model linear regresi berganda yang menggambarkan hubungan antara Good Corporate Governance, leverage dan pertumbuhan total asset sebagai variabel independen terhadap variabel dependen yakni Nilai Perusahaan yang ditunjukkan melalui harga saham. Model Persamaan regresi yang digunakan dirumuskan sebagai berikut

$\mathrm{Y}=\alpha+\beta 1 \times 1+\beta 2 \times 2+\beta 3 \times 3+\beta 4 \times 4+\beta 5 \times 5+\beta 6 \times 6+\mathrm{e}$

Keterangan :

$\mathrm{Y}=$ Nilai Perusahaan / Harga saham

$\alpha=$ konstanta

$\beta 1, \beta 2, \beta 3, \beta 4, \beta 5=$ koefisien regresi

$\mathrm{x} 1=$ kepemilikan manajerial

$\mathrm{x} 2=$ kepemilikan isntitusional

$\mathrm{x} 3=$ proporsi dean komisarfis independen

$\mathrm{x} 4=$ komite audit

$\mathrm{x} 5=$ pertumbuhan total aset

$\mathrm{x} 6=$ leverage

$\mathrm{e}=$ error-terms (faktor error / gangguan) 
III. Hasil Penelitian

Penelitian ini menggunakan populasi perusahaan-perusahaan manufaktur yang terdaftar di BEI tahun 2013-2016, Sampel yang digunakan dalam penelitian ini dipilih dengan menggunakan metode purposive sampling, sehingga sampel dalam penelitian ini merupakan perusahaan yang memiliki kriteria yang sesuai dengan tujuan penelitian. Tabel 1 berikut menyajikan hasil pemilihan sampel dengan menggunakan metode purposive sampling :

Tabel 1

Seleksi Sampel

\begin{tabular}{|c|c|c|}
\hline No & Kriteria Pemilihan Sampel & Jumlah \\
\hline 1. & $\begin{array}{l}\text { Perusahaan manufaktur yang terdaftar di Bursa Efek Indonesia (BEI) } \\
\text { selama periode 2013-2016. }\end{array}$ & 151 \\
\hline 2. & $\begin{array}{l}\text { Perusahaan tersebut mempublikasikan laporan keuangan yang telah } \\
\text { diaudit selama periode } 2013-2016\end{array}$ & 121 \\
\hline 3. & Laporan keuangan dipublikasikan dalam mata uang rupiah & 145 \\
\hline 4. & $\begin{array}{l}\text { Perusahaan tersebut memiliki sekurang-kurangnya tiga anggota } \\
\text { komite audit (BAPEPAM Nomor } 03 \text { tahun 2002) dan (KEP- } \\
\text { 103/MBU/2002) }\end{array}$ & 38 \\
\hline & $\begin{array}{l}\text { Jumlah sampel perusahaan manufaktur } \\
\text { Jumlah sampel observasi penelitian selama } 4 \text { tahun }\end{array}$ & $\begin{array}{l}24 \\
96\end{array}$ \\
\hline
\end{tabular}

Sumber : Data diolah, 2017

Dalam penelitian ini juga dilakukan uji statistik deskriptif yang bertujuan untuk memberikan gambaran atau deskripsi dari suatu data yang dilihat dari jumlah sampel, nilai minimum, nilai rata-rata (mean), dan standar deviasi dari masing-masing variabel. Pada tabel 2 dijelaskan statistik penelitian yang menunjukkan pengukuran statistic deskriptif terhadap mekanisme Good Corporate Governance yang diproyeksikan ke dalam enam variabel yaitu kepemilikan institusional, kepemilikan manajerial, proporsi dewan komisaris, dan komite audit serta leverage dan pertumbuhan total asset.

Tabel 2

Deskriptif Statistik

\begin{tabular}{|c|c|c|c|c|c|}
\hline & & & & $\begin{array}{l}95 \\
\text { Confider } \\
\mathrm{e}\end{array}$ & Inverval \\
\hline & $\mathrm{N}$ & Mean & Std. Deviasi & $\begin{array}{l}\text { Lower } \\
\text { Bound }\end{array}$ & Upper Bound \\
\hline Harga saham & 96 & $\begin{array}{l}415268.19 \\
44\end{array}$ & 2.14440 & 50.0000 & 14250000.00 \\
\hline $\begin{array}{l}\text { Kepemilikan } \\
\text { manajerial }\end{array}$ & 96 & 7.4426 & 11.68473 & 0.05 & 77.1915 \\
\hline $\begin{array}{l}\text { Kepemilikan } \\
\text { institusional }\end{array}$ & 96 & 55.1754 & 232.96756 & 0.21 & 95,00 \\
\hline $\begin{array}{l}\text { Dewan } \\
\text { Komisaris } \\
\text { independen }\end{array}$ & 96 & 41.3056 & 16.00760 & 20.00 & 100,00 \\
\hline
\end{tabular}


JAMIN

E-ISSN (Online) : $2621-3230$

Jurnal Aplikasi Manajemen dan Inovasi Bisnis Volume 1, Nomor 1, Agustus 2018

\begin{tabular}{|l|l|l|l|l|l|}
\hline Komite Audit & 96 & 50.2917 & 32.28545 & 0.00 & 100,00 \\
\hline $\begin{array}{l}\text { Leverage } \\
\text { Pertumbuhan } \\
\text { Total Asset }\end{array}$ & 96 & 552.9154 & $4,607.09500$ & -58.66 & $39.101,90$ \\
\hline
\end{tabular}

Sumber : Data diolah, 2017

Hasil analisis regresi linier berganda digunakan untuk menguji hipotesis tentang pengaruh variabel independen secara parsial. Hasil analisis regresi dapat dilihat pada tabel 3 berikut ini.

Tabel 3

Analisa Regresi Linier Berganda

\begin{tabular}{|l|c|c|c|}
\hline \multirow{2}{*}{ Model } & $\begin{array}{c}\text { Standardized } \\
\text { Cofficient }\end{array}$ & & \\
\cline { 2 - 2 } & Beta & $\mathrm{T}$ & Sig. \\
\hline $\begin{array}{l}\text { (Constant) } \\
\text { Mepemilikan }\end{array}$ & 13,862 & 2,276 & 0,032 \\
\hline $\begin{array}{l}\text { Kepemiliak } \\
\text { Institusional }\end{array}$ & $-0,509$ & 1,098 & 0,022 \\
\hline Dewan Komisaris & $-1,371$ & 0,843 & 0,047 \\
\hline Komite Audit & $-0,63$ & 2,242 & 0,050 \\
\hline Leverage & 0,621 & 1,935 & 0,049 \\
\hline $\begin{array}{l}\text { Pertumbuhan Total } \\
\text { Asset }\end{array}$ & $-0,276$ & $-0,658$ & 0,517 \\
\hline
\end{tabular}

Sumber : Data diolah, 2017

Berdasarkan output persamaan regresi diatas maka rumus persamaan regresinya adalah; $\mathrm{HS}=13,862-0,509 \mathrm{KM}+0,036 \mathrm{KI}-1,371 \mathrm{DKI}-0,630 \mathrm{KA}+0,621 \mathrm{LEV}-0,276 \mathrm{PTA}$

Keterangan ;

HS = Harga Saham

$\mathrm{KM}=$ Kepemilikan Manajerial

$\mathrm{KI}=$ Kepemilikan Institusional

DKI $=$ Dewan Komisaris Independen

KA $=$ Komite Audit

$\mathrm{LEV}=$ Leverage

PTA $=$ Pertumbuhan Total Asset

Dalam pengujian hipotesis, pendekatan $\left(\mathrm{R}^{2}\right)$ digunakan untuk melihat besarnya konstribusi dari seluruh variabel bebas terhadap variabel terikat. Nilai $\left(\mathrm{R}^{2}\right)$ dalam penelitian ini diperoleh dengan bantuan SPSS. Nilai $\left(\mathrm{R}^{2}\right)$ harus lebih besar dari nol (0) dan lebih kecil dari satu (1) atau dengan kalimat matematis $0<\mathrm{R}^{2}<1$. Dari analisis diperoleh hasil nilai $\mathrm{R}^{2}=0,134$. Berarti $0<0,134<1$ dan ini menunjukkan bahwa 13,4\% harga saham dipengaruhi oleh keenam variabel independen. Sedangkan sisanya $86,6 \%$ dipengaruhi oleh variabel lain yang tidak dimasukkan dalam model regresi.

Untuk mengetahui besarnya pengaruh secara parsial variabel independen yaitu variabel kepemilikan manajerial, kepemilikan institusional, proporsi dewan komisaris independen, komite audit, leverage dan pertumbuhan total asset terhadap variabel dependen yaitu nilai perusahaan yang diproksikan dengan harga saham digunakan Uji t. 
Tabel 4

Uji Parsial (t-test)

\begin{tabular}{|l|l|l|l|}
\hline Model & t-hitung & t-tabel & Hasil \\
\hline Konstan & 2,203 & & \\
\hline KM & 2,276 & 1,70814 & Berpengaruh \\
\hline KI & 1,098 & 1,70814 & Berpengaruh \\
\hline PDKI & 0,843 & 1,70814 & Tidak Berpengaruh \\
\hline KA & 2,242 & 1,70814 & Berpengaruh \\
\hline LEV & 1,935 & 1,70814 & Berpengaruh \\
\hline PTA & $-0,658$ & 1,70814 & Tidak berpengaruh \\
\hline
\end{tabular}

Sumber : Data diolah, 2017

Dari hasil uji t menunjukkan bahwa dari 6 variabel yang dimasukkan dalam model regresi diketahui : 1). Hipotesis 1, Variabel kepemilikan manajerial mengukur pengaruh proporsi saham yang dimiliki oleh manajemen terhadap harga saham. Dari hasil pengujian diperoleh kepemilikan manajerial berpengaruh terhadap harga saham. Hal ini terlihat dari nilai $t$ hitung $<\mathrm{t}$ tabel $(2,276>1,70814)$. Sehingga Hipotesis ke1diterima. 2). Dalam Hipotesis 2, variabel kepemilikan institusional mengukur pengaruh proporsi saham yang dimiliki oleh institusi terhadap harga saham. Berdasarkan pengujian yang dilakukan, hasil penelitian ini menunjukkan bahwa kepemilikan institusional berpengaruh terhadap nilai perusahaan. Hal ini terlihat dari nilai $\mathrm{t}$ hitung $<\mathrm{t}$ tabel $(1,098>1,70814)$. Sehingga Hipotesis ke-2 diterima. 3). Hipotesis 3, variabel proporsi dewan komisaris independen mengukur pengaruh proporsi saham yang dimiliki oleh dewan komisaris independen terhadap harga saham. Berdasarkan pengujian yang dilakukan, hasil penelitian ini menunjukkan bahwa variabel proporsi dewan komisaris independen tidak berpengaruh terhadap harga saham. Hal ini terlihat dari nilai t hitung $<\mathrm{t}$ tabel $(0,843<1,70814)$. Sehingga Hipotesis ke-3 Ditolak. 4).

Dalam Hipotesis 4, variabel komite audit mengukur pengaruh proporsi saham yang dimiliki oleh komite audit terhadap harga saham. Berdasarkan pengujian yang dilakukan, hasil penelitian ini menunjukkan bahwa variabel komite audit tidak berpengaruh terhadap harga saham. Hal ini terlihat dari nilai $\mathrm{t}$ hitung $<\mathrm{t}$ tabel $(2,242>$ 1,70814). Sehingga Hipotesis ke-4 Diterima. 5). Hipotesis 5, variabel leverage mengukur pengaruh leverage terhadap nilai perusahaan. Berdasarkan pengujian yang dilakukan, hasil penelitian ini menunjukkan bahwa variabel leverage berpengaruh terhadap harga saham. Hal ini terlihat dari nilai $t$ hitung $<\mathrm{t}$ tabel $(1,935>1,70814)$. Sehingga Hipotesis ke-5 Diterima. 6). Hipotesis 6, mengukur pengaruh variabel pertumbuhan total asset terhadap nilai perusahaan. Berdasarkan pengujian yang dilakukan, hasil penelitian ini menunjukkan bahwa variabel pertumbuhan total asset tidak berpengaruh terhadap harga saham. Hal ini terlihat dari nilai $t$ hitung $<\mathrm{t}$ tabel ($0,658<1,70814)$. Sehingga Hipotesis ke-6 Ditolak.

Jadi dapat disimpulkan bahwa secara partial variabel independen dalam hal kepemilikan manajerial, kepemilikan institusional, komite audit dan leverage berpengaruh terhadap harga saham sedangkan proporsi dewan komisaris independen dan pertumbuhan total tidak berpengaruh terhadap harga saham. Hasil penelitian menunjukkan bahwa Kepemilikan Manajerial berpengaruh secara signifikan terhadap 
nilai perusahaan yang ditunjukkan dengan harga saham pada perusahaan manufaktur. Hasil tersebut sesuai dengan penelitian yang dilakukan oleh Jensen dan Meckling (1976), Anderson et al (2005), Friend dan Lang dalam Brailsford et al (1999). Adanya kepemilikan manajerial dalam kepemilikan saham perusahaan seharusnya memberikan dorongan bagi pihak manajemen untuk meningkatkan kinerjanya. Akan tetapi, proporsi kepemilikan manajerial yang cenderung sedikit menyebabkan pihak manajemen enggan untuk bekerja semaksimal mungkin, sehingga menurunkan nilai perusahaan. Selain itu, penelitian ini konsisten dengan penelitian yang dilakukan oleh Nurlela dan Islahuddin (2009) yang menemukan bahwa struktur kepemilikan manajerial berpengaruh positip terhadap nilai perusahaan.

Hasil penelitian menunjukkan bahwa Kepemilikan Institusional berpengaruh secara signifikan terhadap nilai perusahaan yang ditunjukkan dengan harga saham pada perusahaan manufaktur. Dari penjelasan tersebut diatas juga dapat disimpulkan bahwa nilai perusahaan dapat meningkat jika lembaga institusi mampu menjadi alat pemonitoran yang efektif. Menurut Ardita (2010) pihak institusi mungkin hanya memanfaatkan kepemilikan saham untuk spekulasi saja, sehingga tidak memperhatikan pengelolaan perusahaan. Penelitian ini tidak sesuai dengan penelitian yang dilakukan oleh Bhojraj dan Sengupta (2003), Agrawal dan Maldeker (1990) serta Crutchley et al (1999). Hal ini menunjukkan bahwa adanya kepemilikan institusional memberikan pengaruh yang berarti sebagai tindakan monitoring yang dilakukan kepada pihak manajemen. Semakin besar tingkat kepemilikan saham oleh institusi, maka semakin efektif pula mekanisme control terhadap kinerja manajemen sehingga meningkatkan nilai perusahaan.

Hasil penelitian menunjukkan bahwa Proporsi Dewan Komisaris Independen tidak berpengaruh secara signifikan terhadap nilai perusahaan yang ditunjukkan dengan harga saham pada perusahaan manufaktur. Hasil penelitian ini mendukung penelitian terdahulu yang dilakukan oleh Girsang (2010) dan Nurhayati (2010) tetapi bertentangan dengan hasil yang diperoleh Isnanta (2007). Perbedaan penelitian ini mungkin disebabkan oleh periode penelitian pada periode 2005-2006, dimana pada tahun tersebut, kondisi perekonomian Indonesia tidak berada dalam kondisi moneter seperti yang dialami oleh perusahaan pada tahun 2007-2008 sehingga para anggota dewan komisaris dapat memberikan informasi yang pasti dan perkembangan penting perusahaan secara cepat dan tepat yang pada akhirnya dapat mempengaruhi nilai perusahaan.

Hasil penelitian menunjukkan bahwa komite audit berpengaruh secara signifikan terhadap nilai perusahaan. Penelitian ini konsisten dengan penelitian yang dilakukan oleh Isnanta (2007) dan Girsang (2010) yang menemukan bahwa keberadaan anggota komite audit independen tidak efektif untuk mendorong kenaikan harga saham yang dapat meningkatkan nilai perusahaan. Hal ini karena pengakuan komite audit oleh perusahaan hanya dilakukan untuk pemenuhan regulasi saja tetapi tidak dimaksudkan untuk menegakkan Good Corporate Governance di perusahaan. Hal ini terlihat dari proporasi anggota komite audit yang independen lebih sedikit dari keseluruhan jumlah anggota komite audit. Hasil penelitian menunjukkan bahwa Leverage berpengaruh secara signifikan terhadap nilai perusahaan yang ditunjukkan dengan harga saham pada perusahaan manufaktur.

Penelitian konsisten dengan penelitian Novaes (2002) menyatakan bahwa peningkatan leverage bisa memberikan dua macam signal, yaitu berita baik (good news) sekaligus berita buruk ( $\mathrm{bad}$ news). Peningkatan leverage menunjukkan berita baik jika 
peningkatan tersebut merefleksikan kemampuan managemen untuk meningkatkan nilai. Sebaliknya, hal tersebut menunjukkan berita buruk jika manager melakukan peningkatan leverage karena terpaksa dan bukan karena alasan efisiensi.Hasil penelitian menunjukkan bahwa Pertumbuhan Total Asset tidak berpengaruh secara signifikan terhadap nilai perusahaan yang ditunjukkan dengan harga saham pada perusahaan manufaktur. Penelitian ini konsisten dengan penelitian yang dilakukan oleh Widhasa (2010) yang menemukan bahwa pertumbuhan total asset tidak berpengaruh terhadap harga saham. Pertumbuhan total asset tinggi, maka akan mencerminkan pendapatan meningkat sehingga nilai perusahaan cenderung meningkat. Sedangkan data pada penelitian ini menunjukkan bahwa terjadi kenaikan dan penurunan terhadap total asset sehingga hasil penelitian ini menunjukkan bahwa pertumbuhan total asset tidak berkontribusi terhadap nilai perusahaan.

IV. Kesimpulan dan Saran

A. Kesimpulan

Pengaruh mekanisme Good Corporate Governance, Leverage, dan Pertumbuhan Total Aset secara parsial ditunjukkan sebagai berikut :

A. Mekanisme kepemilikan manajerial berpengaruh terhadap nilai perusahaan. Hasil penelitian konsisten dengan penelitian yang dilakukan oleh Jensen dan Meckling (1976), Anderson et al (2005), Friend dan Lang dalam Brailsford et al (1999). Dimana kepemilikan manajerial dalam kepemilikan saham perusahaan seharusnya memberikan dorongan bagi pihak manajemen untuk meningkatkan kinerjanya.

B. Mekanisme kepemilikan institusional berpengaruh terhadap nilai perusahaan. Penelitian ini sesuai dengan penelitian yang dilakukan oleh Bhojraj dan Sengupta (2003), Agrawal dan Maldeker (1990) serta Crutchley et al (1999). Hal ini menunjukkan bahwa adanya kepemilikan institusional memberikan pengaruh yang berarti sebagai tindakan monitoring yang dilakukan kepada pihak manajemen. Semakin besar tingkat kepemilikan saham oleh institusi, maka semakin efektif pula mekanisme kontrol terhadap kinerja manajemen sehingga meningkatkan nilai perusahaan.

C. Mekanisme proporasi dewan komisaris independen tidak berpengaruh terhadap nilai perusahaan. Hasil penelitian ini mendukung penelitian terdahulu yang dilakukan oleh Girsang (2010) dan Nurhayati (2010) tetapi bertentangan dengan hasil yang diperoleh Isnanta (2007).

D. Mekanisme komite audit berpengaruh terhadap nilai perusahaan. Penelitian ini konsisten dengan penelitian yang dilakukan oleh Isnanta (2007) dan Girsang (2010) yang menemukan bahwa keberadaan anggota komite audit independen tidak efektif untuk mendorong kenaikan harga saham yang dapat meningkatkan nilai perusahaan. Hal ini karena pengakuan komite audit oleh perusahaan hanya dilakukan untuk pemenuhan regulasi saja tetapi tidak dimaksudkan untuk menegakkan Good Corporate Governance di perusahaan.

E. Variabel leverage berpengaruh terhadap nilai perusahaan.

F. Hasil penelitian ini mendukung penelitian Novaes (2002) dimana peningkatan leverage menunjukkan berita baik jika peningkatan tersebut merefleksikan kemampuan managemen untuk meningkatkan nilai. Sebaliknya, hal tersebut menunjukkan berita buruk jika manager melakukan peningkatan leverage karena terpaksa dan bukan karena alasan efisiensi.

G. Variabel pertumbuhan total aset tidak berpengaruh terhadap nilai perusahaan. 
H. Penelitian ini konsisten dengan penelitian yang dilakukan oleh Widhasa (2010) yang menemukan bahwa pertumbuhan total asset tidak berpengaruh terhadap harga saham. Dimana pertumbuhan total asset tinggi, maka akan mencerminkan pendapatan meningkat sehingga nilai perusahaan cenderung meningkat. Sedangkan data pada penelitian ini menunjukkan bahwa terjadi kenaikan dan penurunan terhadap total asset sehingga hasil penelitian ini menunjukkan bahwa pertumbuhan total asset tidak berkontribusi terhadap nilai perusahaan.

B. Saran

Berdasarkan hasil penelitian, temuan dan keterbatasan penelitian, maka selanjutnya dirumuskan beberapa rekomendasi yang ditunjukkan kepada para peneliti lanjutan, khususnya yang berkaitan dengan pengaruh Good Corporate Governance antara lain ;

1. Menggunakan secara lengkap prinsip-prinsip Good Corporate Governance dengan lebih mengembangkan indikator-indikator selain yang digunakan dalam penelitian ini, seperti implementasi Good Corporate Governance di lapangan misalnya tugas dan tanggung jawab dewan komisaris dan komite audit perusahaan.

2. Menggunakan sampel yang tidak terbatas pada perusahaan manufaktur tetapi perusahaan dagang dan jasa yang lain yang terdaftar di Bursa Efek Indonesia.

3. Bagi perusahaan diharapkan dapat menerapkan Good Corporate Governance di dalam perusahaan. Bagi perusahaan yang telah menerapkan Good Corporate Governance diharapkan penerapan dari Good Corporate Governance tersebut sesuai dengan tujuan dikeluarkannya yaitu agar terciptanya perusahaan yang sehat dan bersih.

\section{Daftar Pustaka}

Ahmar dan Kurniawan, 2007. Analisis Prfitabilitas Sebelum dan Seusdah Pemenuhan Corporate Governance pada Perusahaan Manufaktur yang Go Public di Bursa Efek Jakarta.” Jurnal MAKSI. Vol 7 No. 3, Agustus.

Andayani, Wuryan dkk, 2008, Corporate Social Responsibility, Good Corporate Governance and the Intellectual Property: An External Strategy of the the management to increase the company's value. National conference on management research. Makassar, 27 November 2008.

Anderson, R.C., Mansi, S.A. \& Reeb, D.M (2005). Controlling managerial opportunism. Retrived from: www.fma.org/Chicago/papers/controlling managerial opportunism.pdf.

Ardita, Alisia, 2010. Pengaruh penerapan Good Corporate Governance dengan kinerja saham. Skripsi. Smearang; Universitas Diponegoro.

Arifin, Zaenal, 2005. " Hubungan antara Corporate Governance dan variabel pengurang masalah agensi." Jurnal siasat bisnis, vol. 1 No. 10, Juni 2005, hal 39-55.

Black, B.S, W.Kim, H. Jang, dan K.S park (2002), : "Does Corporat Governance affect firm value? Evidence from Korea". Finance Working paper, No. 103, http://www.ssrn.com.

Bhojraj, Sanjeev \& Segupta, Partha (2003) effect of corporate on bond ratings and yield: the role of institusional investor and outside directors. Retrieved from : hhtp://ssrn.com/abstract $=291056$

Brigham \&Houston, 2010. Financial Manajemen Dasar-dasar Manajemen Keuangan. Edisi terjemah. Jakarta: Salemba Empat. 
Carningsih, 2007. Pengaruh Good Corprate Governance terhadap hubungan antara kinerja keuangan dengan nilai perusahaan (studi kasus pada perusahaan property dan real estate yang terdaftar di bursa efek Indonesia). Universitas Gunadarma.

Dietiana, Tita (2011), Pengaruh rasio keuangan, pertumbuhan penjualan, dan deviden terhadap harga saham. Jurnal Bisnis dan Akuntansi. Vol. 13. No. 1, April 2011. Hlm 57-66

Girsang, Isisn Mahdalena (2010). “Pengaruh Good Corporate Governance terhadap manajemen laba dan kinerja perusahaan real estate dan property yang terdaftar di bursa efek Indonesia." Skripsi, jurusan akuntansi, Fakultas ekonomi, universitas Sumatera Utara, Medan.

Gupta dkk, 2007, Corporate Governance and Firm Value: evidence from Canadian capital markets. http ://ssrn.com/abstract=1366045

Gusnadi dan pratiwi Budiharta, 2008."Analisis pengaruh karakteristik perusahaan dan penerapan Good Corporate Governance terhadap tindakan perataan laba yang dilakukan oleh perusahaan yang terdaftar di bursa efek Jakarta." MODUS Vol 20 (2):126-138, Jakarta.

Herawaty, Vinolla, 2008." Peran Praktek Corporate Governance sebagai moderating variable dari pengaruh earning management terhadap nilai perusahaan" Jurnal Akuntansi dan Keuangan. Vol. 10, No.2, pp 97-108.

Isnanta, Rudi, 2007. “Pengaruh Good Corporate Governance dan struktur kepemilikan terhadap manajemen laba dan kinerja perusahaan manufaktur yang terdaftar di Bursa Efek Indonesia." Skripsi, Jurusan Akuntansi, Fakultas Ekonomi, Universitas Islam Indonesia, Yogyakarta.

Indrawati, Titik dan Suhendro, 2006. Determinasi Capital Structure pada perusahaan manufaktur di Bursa Efek Jakarta Periode 2000-2004, Jurnal Akuntansi dan Keuangan Indonesia, Vol. 3, No.1, Januari-Juni, hlm. 77-105.

Jensen, M.C., \&Meckling, W.H. (1976). Theory of the firm: managerial behavior agency cost and ownership structure. Journal of Financial Economics, 3 (4), 305-360.

Jogiyanto, 2009, Teori Portofolio dan Analisis Investasi, BPFE, Yogyakarta.

Murwaningsari, 2009, Hubungan corporate governance, corporate Social responsibility dan Corporate financial performance, Jurnal Akuntansi dan Keuangan.

Nurhayati, Nanik, 2010, "Pengaruh Good Corporate Governance terhadap kinerja perusahaan perbankan yang sudah terdaftar di BEI." Tesis, jurusan kauntansi, Universitas Muhammadiyah Malang

Murlela, Rika dan Islahuddin, 2008. Pengaruh Good Corporate Governance terhadap nilai perusahaan dengan prosentase kepemilikan manajemen sebagai variabel moderating, symposium nasional akuntansi XI, Pontianak.

Novianti, lenny, 2009. “Penerapan Good Corporate Governance di Indonesia, Jurnal Akuntansi dan Keuangan Indonesia, Vol. 14, No.2, Juli 2009, hlm. 77-105, hlm. 211-234.

Rustiarini, NI Wayan. 2010. Pengaruh Corporate Governance pada hubungan Corporate Social Responsibility dan Nilai Perusahaan. Simposium Nasional akuntansi XIII Purwokerto.

Sukamulja, Sukmawati, 2004." Good Corporate Governance di sector keuangan ; Dampak Good Corporate Governance terhadap kinerja keuangan." Vol .8 No.1 Juni 2004. Hal 125.

Siallagan, Hamoonangan dan Machfoedz, Mas'ud. 2006."Mekanisme Corporate Governance, Kualitas Laba dan Nilai Perusahaan”. Simposium Nasional IX. Padang, 23-26 Agustus 2006.

Watts R. and J.L. Zimmerman. 1986. Positive Accounting Theory. New York. Pentice Hall. 